MUDRA: Journal of Finance and Accounting, Volume 4, Issue 2, July-December 2017, pp. 62-71 doi: 10.17492/mudra.v4i02.11448

\title{
Customer Relationship Management Practices and Customer Loyalty in Commercial Banks: An Empirical Study
}

\author{
Linie Darli* and R.Vasanthagopal**
}

\begin{abstract}
Differentiating products through best practices, providing timely services to encourage word of mouth publicity, and increasing quality of services through best practices have become benchmarks in retail banking sector in India. A number of research studies have been performed that have highlighted the importance of Customer Relationship Management (CRM) in banking industry and its contribution to customer satisfaction and retention. This empirical paper closely examines the association between CRM best practices and customer loyalty in commercial banks in Kerala. The assessment done based on the opinion of customers exposed that there is a good association between CRM practices and customer loyalty in commercial banks in Kerala.
\end{abstract}

Keywords: Customer Relationship Management (CRM); Commercial banks; Retail banking; Best practices; Customer loyalty.

\subsection{Introduction}

Banking sector has started differentiating their products and services by adopting best practices. If the customers are happy with the best practices adopted by banks, normally they will keep long term relations with the bank. Customers have their own perceptions about each type of services offered by banks. Banks try to satisfy these perceptions or expectations and convince the customer that they are offering quality services. Loyalty of customers usually depends on the quality of services offered by banks in their banking needs. Loyalty programmes are structured marketing strategies adopted by banks to encourage customers to continue to use the services of the banks.

\footnotetext{
*HSST Commerce, St. Joseph's Convent Girls HSS, Thrissur, Kerala, India. (Email id: liniedarli@hotmail.com)

**Corresponding author; Assistant Professor, School of Distance Education, University of Kerala, Thiruvananthapuram, Kerala, India. (Email id: vasanthagopalr@yahoo.com)
} 
Banks have started providing timely services to increase customer satisfaction and to reduce customer attrition. Once the customers avail themselves of timely services from their bank, then customers will be convinced about the consideration the bank shows to them and start getting the feel of satisfaction leading to loyalty. This help banks increase profitability and further augment them increase their efforts to offer improved services to customers and this circle continues. Customised services and products to key customers, strive to constantly surprise and delight key customers, strengthen the emotional bonds with key customers by wishing them on important occasions, use the concept of 'relationship pricing' in pricing different products/ services, use cobranding/affinity partnering programmes to provide increased value to customers, leverage the power of word of mouth by using referral marketing programmes and cross selling of products/services to increase customer share are the practices generally employed by banks for enhancing customer loyalty in India. No doubt, employees are very instrumental in expunging these practices effectively to get the desired returncustomer loyalty. For that too banks develop tailor made training programmes for their employees. The study has been made to find the association between CRM practices and customer loyalty in commercial banks in Kerala. Accordingly, the study advanced with the hypothesis that there is a good association between CRM practices and customer loyalty in commercial banks in Kerala.

\subsection{Review of Literature}

The expense of acquiring customers is incurred only at the beginning stages of the commercial relationship, longer-term customers buy more and, if satisfied, may generate positive word-of-mouth promotion for the company (Reichheld and Kenny, 1990). Further, long-term customers take less of the company's time and are less sensitive to price changes highlighting the opportunity for management to acquire referral business, as it is often of superior quality and inexpensive to obtain (Healy, 1999). The aim of relationship marketing is to establish, maintain, and enhance relationships with customers and other partners, at a profit, so that the objectives of the parties involved are met (Gronroos, 1994). Additionally, web based services have to be more convenient, easier to use, and less expensive than the alternative, which can increase quality in services to win the loyalty of consumers (Cronin, 1998). A loyal customer will work as an ambassador to the bank and facilitate growth of business (Bhasker, 2004). Furthermore, long term customer relationship behaviour can be evaluated in the form of repurchase, word of mouth, and increasing the scale and scope of a relationship (Jacoby and Kyner, 1973). Today's customers do not just buy core 
quality products or services; they also buy a variety of added value or benefits. This forces the service providers such as banks to adopt a market orientation approach like loyalty programs that identify consumer needs and design new products and redesign current ones (Ennew and Binks, 1996, and Woodruff 1997). Commitment was the most common dependent variable used in buyer-seller relationship studies and it can be enriched through offering products and services at reasonable cost (Wilson, 1995). Internet related innovativeness is positively related to the adoption of online banking which increases comfort of the customer (Lassar et al. 2005).

\subsection{Methodology}

All the public and private sector commercial banks in Kerala constitute the universe for the study. Multistage sampling technique was employed for selecting the sample. In the first stage, the State of Kerala was divided into three zones- south, central and north and accordingly Thiruvananthapuram (representing the south), Thrissur (representing the central) and Kozhikode (representing the north) were selected. In the second stage, SBI from the public sector and Federal bank from the private sector were selected from each of the three sample districts, based on the volume of business and number of branches. In the third stage, for selecting the sample branch, 15 bank branches each of SBI and Federal bank from the three zones were selected randomly. Thus, a total of 90 branches (45 SBI branches and 45 Federal bank branches) constitute the sample branches. In the fourth stage, the sample customers were selected. Five customers each from 45 branches of SBI and 45 branches of Federal Bank were selected purposively. Thus, a total of 450 were the respondents (225 customers each from SBI and Federal bank), representing the respondents for the study. For data analysis, statistical tools such as average, percentage, standard deviation, correlation, Chi-square test, t-test, $\mathrm{z}$ test, ANOVA, and Factor Analysis were used.

\subsection{Results and Discussion}

To assess the association of CRM best practices and customer loyalty in the retail banking sector in Kerala, the respondents were asked their opinion on 27 pretested practices (Table 1). The responses were scored as 1 for 'strongly disagree', 2 for 'disagree', 3 for 'no opinion', 4 for 'agree' and 5 for 'strongly agree'.

The association between CRM practices and customer loyalty in the retail banking sector in Kerala has been made through structural equation modeling (SEM). 
The SEM estimation procedure used for the analysis here is maximum likelihood estimation.

\section{Table 1: CRM Practices Selected for the Study}

\begin{tabular}{|c|c|}
\hline SI No & CRM Practices \\
\hline IV 1 & Customers are loyal because of the reputation of bank \\
\hline IV 2 & Customers are loyal because of quality in the services \\
\hline IV 3 & $\begin{array}{l}\text { Customers keep long relationship with bank because of the best practices adopted by } \\
\text { bank }\end{array}$ \\
\hline IV 4 & Customers are loyal to bank because of the loyalty programs adopted by bank \\
\hline IV 5 & Timely services of banks keep the customers loyal \\
\hline IV 6 & Comfort ability of bank and services keep the customers loyal \\
\hline IV 7 & Caring given by bank for customers makes customers loyal \\
\hline IV 8 & Interest shown by bank towards customers' services influences customer loyalty \\
\hline IV 9 & Customer loyalty increases due to reliability of services \\
\hline IV 10 & Response of employees to customers keeps the customers loyal \\
\hline IV 11 & $\begin{array}{l}\text { Empathetic attitude (to think from customers point of view) shown by employees } \\
\text { towards customer's increases customer loyalty }\end{array}$ \\
\hline IV 12 & Flexibility of employees in extending services contributes to customer loyalty \\
\hline IV 13 & $\begin{array}{l}\text { If customers get services up to their expectations they will stick on to a bank leading to } \\
\text { customer loyalty }\end{array}$ \\
\hline IV 14 & $\begin{array}{l}\text { Faith in banks products and services is an important factor contributing to customer } \\
\text { loyalty }\end{array}$ \\
\hline IV 15 & $\begin{array}{l}\text { Customers who are kept in queue for a long time will negatively affect customer } \\
\text { loyalty }\end{array}$ \\
\hline IV 16 & $\begin{array}{l}\text { Habitual behavioural pattern of customers will make them stick on to a bank due to } \\
\text { their behaviour }\end{array}$ \\
\hline IV 17 & Nearness to bank is a factor influencing customer loyalty \\
\hline IV 18 & $\begin{array}{l}\text { Even though customers are not satisfied with a bank, they don't shift due to many } \\
\text { other reasons }\end{array}$ \\
\hline IV 19 & Banks available nearby is a factor influencing customer loyalty \\
\hline IV 20 & $\begin{array}{l}\text { Switching barriers (unable to change bank without incurring expenses) are another } \\
\text { factor which keeps customers loyal }\end{array}$ \\
\hline IV 21 & Some customers are loyal because they don't want to shift to other banks \\
\hline IV 22 & Service quality keeps the customers with a bank \\
\hline IV 23 & If bank is trustworthy, customers never think of shifting their account \\
\hline IV 24 & A satisfied customer is a loyal customer \\
\hline IV 25 & A loyal customer has long term relationship with the bank \\
\hline IV 26 & Best practices adopted by bank contribute to customer loyalty \\
\hline IV 27 & A loyal customer will help bank in marketing through 'word of mouth' publicity \\
\hline
\end{tabular}

Source: Primary data. 
For the analysis, initially an input model was developed by using AMOS-18 graphics (Figures 1 and 2). The rectangle represents observed factors, the ovals drawn in the diagram represents unobserved variable. The curved double headed arrows represent correlations or co-variances among the unobserved variables and the straight headed arrow represents the factor loadings of the observed variables. The small circles with arrows pointing from the circles to the observed variables represent errors /unique factors, which are also known as, squared multiple correlation of the standard error. The SEM starts with an initial model and refined to reach the final model. The model fit indices are presented in Table 2 .

Figure 1 and 2: CFA Chart on CRM Best Practices and Customer Loyalty for

\section{Customers}
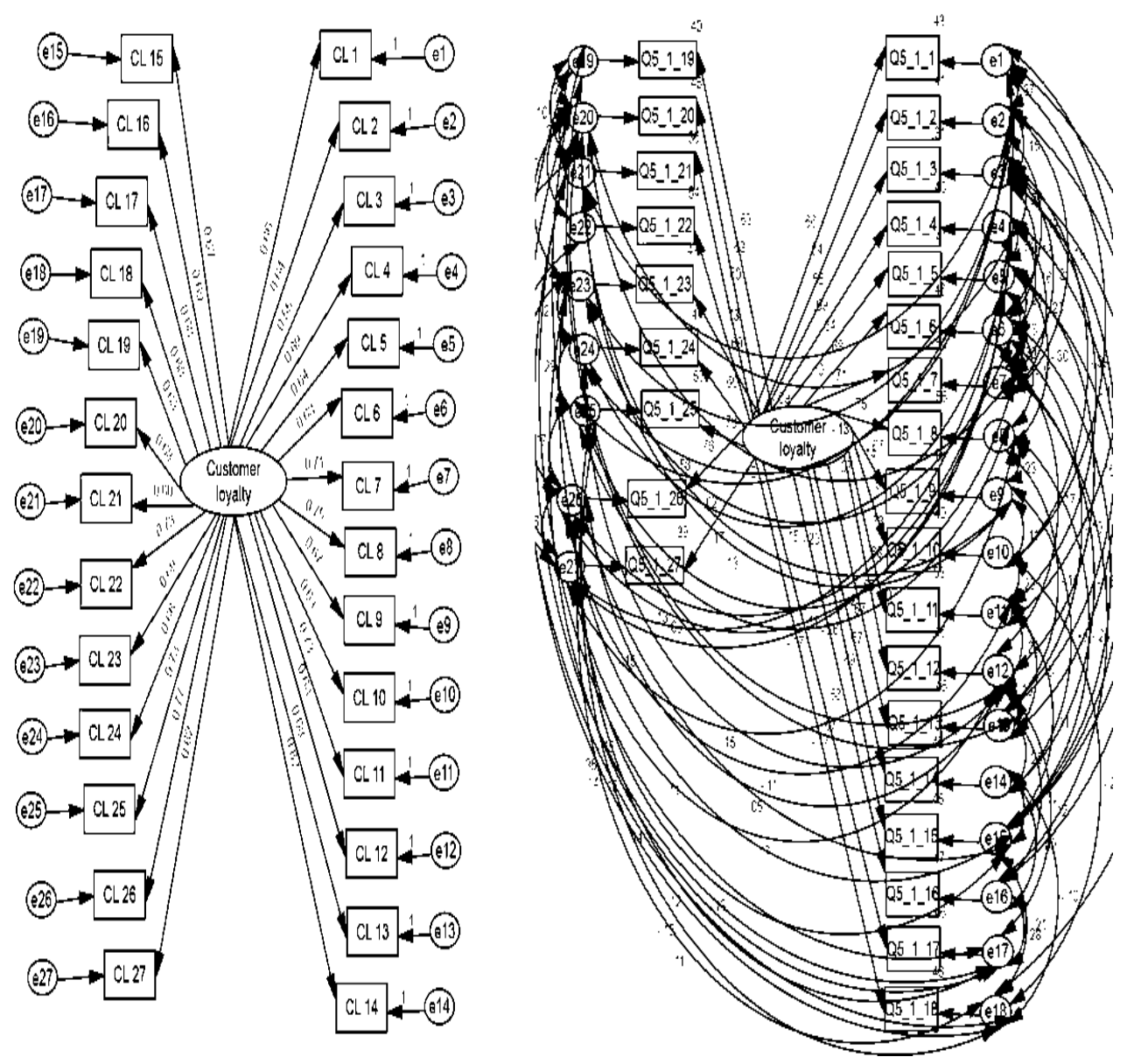
Table 2: Model Fit Indices for CFA CRM Best Practices and Customer Loyalty

\begin{tabular}{|c|c|c|c|c|c|c|c|c|c|c|c|}
\hline & $\chi^{2}$ & DF & p & $\begin{array}{c}\text { Normed } \\
\chi^{2} \\
\end{array}$ & GFI $^{1}$ & AGFI $^{2}$ & $\mathbf{N F I}^{3}$ & TLI $^{4}$ & $\mathrm{CFI}^{5}$ & $\mathbf{R M R}^{6}$ & $\begin{array}{r}\text { RMS } \\
\text { EA }^{7} \\
\end{array}$ \\
\hline Association & 374.09 & 229 & .00 & 1.63 & .95 & .91 & .95 & .97 & .98 & .034 & .04 \\
\hline
\end{tabular}

1. GFI stands for Goodness of Fit Index: It's an absolute fit measure. Higher values closure to 1.0 indicates better fit.

2. AGFI stands for Adjusted Goodness of Fit Index: It's an incremental fit measure. A recommended value of AGFI is 0.09 or greater. The value closure to 1.0 indicates perfect fit.

3. NFT stands for Normal Fit Index: It's an incremental fit measure. A recommended value of NFI is 0.09 or greater. The value closure to 1.0 indicates perfect fit.

4. TLI stands for Tuker-Lewis Index: It's an incremental fit measure. A recommended value of TLI is 0.09 or greater. The value closure to 1.0 indicates perfect fit.

5. CFI stands for Comparative Fit Index. It's an incremental fit measure. Higher values closure to 1.0 indicates better fit. 6. RMR stands for Root mean Square Residual: It's an absolute fit measure. Smaller values are better.

7. RMSEA stands for Root Mean Square Error of Approximation: It's an absolute fit measure. Values ranging from .05 to 0.08 are acceptable.

Source: Primary data.

The validity of the hypothesis was also assessed by examining the correlation coefficients. Pearson Correlation was seen as appropriate to analyse the relationship between the two variables which were interval-scaled and ratio-scaled. Furthermore, correlation coefficients reveal magnitude and direction of relationships which are suitable for hypothesis testing. The correlation calculated here shows a value of 0.783 , which gives a significant positive correlation between CRM best practices and customer loyalty (Table 3). So they have significant impact on association of CRM best practices and customer loyalty. Hence the null hypothesis stating that there is a good association between CRM best practices and customer loyalty in commercial banks in Kerala stands accepted. However, this finding is contradictory to the findings of Das (2009) which state that there is no association between CRM best practices and customer loyalty.

Table 3: Correlation between CRM Best Practices and Customer Loyalty

\begin{tabular}{|c|c|c|c|c|c|}
\hline Variables & Correlation & Lower bound & Upper bound & $\mathbf{Z}$ & P \\
\hline $\begin{array}{c}\text { CRM Practices and } \\
\text { customer loyalty }\end{array}$ & 0.783 & 0.771 & 0.795 & $\begin{array}{c}26.64 \\
4\end{array}$ & $<0.001$ \\
\hline
\end{tabular}
Source: Primary data.

The relationship between CRM best practices and customer loyalty to personal profile of the customers has also been analysed in the study by applying ANOVA test. Out of 8 variables selected, four variables like age in south Kerala, occupation in central Kerala, qualification in south Kerala and length of association with bank in Central Kerala finds significant association. However, with regard to bank, gender, marital status and annual income, no significant association has been found (Table 4). 
68 | MUDRA: Journal of Finance and Accounting, Volume 4, Issue 2, Jul-Dec 2017

Table 4: Relationship between Association of CRM Best Practices with Customer Loyalty and Personal Variables of Customers

\begin{tabular}{|c|c|c|c|c|c|c|c|}
\hline Variable & Region & Category & No. & Mean & $S D$ & $F$ & Sig. \\
\hline \multirow{6}{*}{ Bank } & \multirow[t]{2}{*}{ South Kerala } & SBT & 75 & 68.03 & 10.50 & \multirow[t]{2}{*}{0.748} & \multirow[t]{2}{*}{$0.456 * *$} \\
\hline & & Federal Bank & 75 & 66.65 & 11.94 & & \\
\hline & \multirow{2}{*}{$\begin{array}{l}\text { Central } \\
\text { Kerala }\end{array}$} & SBT & 75 & 64.91 & 13.87 & \multirow[t]{2}{*}{-1.800} & \multirow[t]{2}{*}{$0.074 * *$} \\
\hline & & Federal Bank & 75 & 68.69 & 11.82 & & \\
\hline & \multirow[t]{2}{*}{ North Kerala } & SBT & 75 & 67.49 & 10.07 & \multirow[t]{2}{*}{0.830} & \multirow[t]{2}{*}{$0.408 * *$} \\
\hline & & Federal Bank & 75 & 65.97 & 12.25 & & \\
\hline \multirow[t]{18}{*}{ Age } & \multirow[t]{6}{*}{ South Kerala } & Below 20 & 24 & 66.71 & 10.69 & \multirow[t]{6}{*}{2.300} & \multirow[t]{6}{*}{$0.048^{*}$} \\
\hline & & $20-30$ & 14 & 65.57 & 14.75 & & \\
\hline & & $30-40$ & 34 & 69.38 & 9.17 & & \\
\hline & & $40-50$ & 49 & 66.96 & 8.37 & & \\
\hline & & $50-60$ & 25 & 69.52 & 9.65 & & \\
\hline & & 60 and above & 4 & 51.00 & 34.47 & & \\
\hline & \multirow{6}{*}{$\begin{array}{l}\text { Central } \\
\text { Kerala }\end{array}$} & Below 20 & 45 & 64.56 & 10.95 & \multirow[t]{6}{*}{1.191} & \multirow[t]{6}{*}{$0.317 * *$} \\
\hline & & $20-30$ & 8 & 74.50 & 4.54 & & \\
\hline & & $30-40$ & 33 & 67.33 & 17.54 & & \\
\hline & & $40-50$ & 42 & 68.64 & 12.81 & & \\
\hline & & $50-60$ & 16 & 64.50 & 9.24 & & \\
\hline & & 60 and above & 6 & 63.67 & 12.93 & & \\
\hline & \multirow[t]{6}{*}{ North Kerala } & Below 20 & 27 & 66.11 & 10.99 & \multirow[t]{6}{*}{2.123} & \multirow[t]{6}{*}{$0.066 * *$} \\
\hline & & $20-30$ & 17 & 74.24 & 5.38 & & \\
\hline & & $30-40$ & 37 & 65.73 & 9.71 & & \\
\hline & & $40-50$ & 51 & 66.39 & 12.86 & & \\
\hline & & $50-60$ & 17 & 64.18 & 11.58 & & \\
\hline & & 60 and above & 1 & 54.00 & & & \\
\hline \multirow[t]{6}{*}{ Gender } & \multirow[t]{2}{*}{ South Kerala } & Male & 76 & 67.05 & 11.91 & \multirow[t]{2}{*}{-0.317} & \multirow[t]{2}{*}{$0.752 * *$} \\
\hline & & Female & 74 & 67.64 & 10.56 & & \\
\hline & Central & Male & 46 & 67.93 & 11.33 & 0.711 & $0.478 * *$ \\
\hline & Kerala & Female & 104 & 66.30 & 13.67 & & \\
\hline & North Kerala & Male & 60 & 65.22 & 13.15 & -1.358 & $0.177 * *$ \\
\hline & & Female & 90 & 67.74 & 9.64 & & \\
\hline Marital & South Kerala & Single & 36 & 67.17 & 12.50 & -0.106 & $0.916 * *$ \\
\hline status & & Married & 114 & 67.39 & 10.86 & & \\
\hline & Central & Single & 55 & 65.75 & 10.45 & -0.756 & $0.451 * *$ \\
\hline & Kerala & Married & 95 & 67.41 & 14.26 & & \\
\hline & North Kerala & Single & 38 & 68.21 & 10.70 & 0.940 & $0.349 * *$ \\
\hline & & Married & 112 & 66.23 & 11.37 & & \\
\hline Qualification & South Kerala & Below SSLC & 20 & 66.25 & 10.11 & 2.709 & $0.023^{*}$ \\
\hline & & SSLC & 31 & 63.97 & 11.32 & & \\
\hline & & Higher secondary & 32 & 71.13 & 9.11 & & \\
\hline & & Graduate & 34 & 70.62 & 7.49 & & \\
\hline & & Post graduate & 19 & 62.84 & 16.76 & & \\
\hline & & Professional & 14 & 65.86 & 12.11 & & \\
\hline
\end{tabular}




\begin{tabular}{|c|c|c|c|c|c|c|c|}
\hline & \multirow{6}{*}{$\begin{array}{l}\text { Central } \\
\text { Kerala }\end{array}$} & Below SSLC & 3 & 73.67 & 2.89 & \multirow[t]{6}{*}{2.188} & \multirow[t]{6}{*}{$0.059 * *$} \\
\hline & & SSLC & 40 & 64.83 & 11.09 & & \\
\hline & & Higher secondary & 41 & 69.41 & 12.12 & & \\
\hline & & Graduate & 31 & 70.42 & 9.35 & & \\
\hline & & Post graduate & 23 & 63.04 & 14.61 & & \\
\hline & & Professional & 12 & 60.58 & 21.99 & & \\
\hline & \multirow[t]{6}{*}{ North Kerala } & Below SSLC & 12 & 64.17 & 9.50 & \multirow[t]{6}{*}{1.333} & \multirow[t]{6}{*}{$0.254 * *$} \\
\hline & & SSLC & 35 & 63.94 & 14.55 & & \\
\hline & & Higher secondary & 37 & 68.86 & 10.95 & & \\
\hline & & Graduate & 30 & 69.17 & 8.81 & & \\
\hline & & Post graduate & 28 & 67.04 & 8.96 & & \\
\hline & & Professional & 8 & 62.75 & 11.60 & & \\
\hline \multirow[t]{18}{*}{ Occupation } & \multirow[t]{6}{*}{ South Kerala } & Business & 26 & 69.04 & 8.24 & \multirow[t]{6}{*}{1.713} & \multirow[t]{6}{*}{$0.135 * *$} \\
\hline & & Employment & 34 & 64.32 & 15.64 & & \\
\hline & & Profession & 19 & 65.79 & 7.35 & & \\
\hline & & Service & 16 & 73.56 & 8.46 & & \\
\hline & & Agriculture & 7 & 66.57 & 6.83 & & \\
\hline & & Others & 48 & 67.21 & 10.95 & & \\
\hline & \multirow{6}{*}{$\begin{array}{l}\text { Central } \\
\text { Kerala }\end{array}$} & Business & 19 & 65.68 & 13.08 & \multirow[t]{6}{*}{2.794} & \multirow[t]{6}{*}{$0.019 *$} \\
\hline & & Employment & 29 & 66.14 & 18.33 & & \\
\hline & & Profession & 18 & 75.00 & 5.73 & & \\
\hline & & Service & 19 & 60.05 & 13.53 & & \\
\hline & & Agriculture & 4 & 72.00 & 0.00 & & \\
\hline & & Others & 61 & 66.80 & 10.44 & & \\
\hline & \multirow[t]{6}{*}{ North Kerala } & Business & 24 & 62.46 & 16.71 & \multirow[t]{6}{*}{1.328} & \multirow[t]{6}{*}{$0.255^{* *}$} \\
\hline & & Employment & 34 & 69.12 & 9.19 & & \\
\hline & & Profession & 17 & 68.18 & 7.04 & & \\
\hline & & Service & 18 & 65.33 & 10.47 & & \\
\hline & & Agriculture & 4 & 72.25 & 2.06 & & \\
\hline & & Others & 53 & 66.74 & 10.74 & & \\
\hline \multirow{12}{*}{$\begin{array}{l}\text { Annual } \\
\text { income }\end{array}$} & \multirow[t]{4}{*}{ South Kerala } & Below 1 lakh & 54 & 65.69 & 11.20 & \multirow[t]{4}{*}{0.626} & \multirow[t]{4}{*}{$0.599 * *$} \\
\hline & & 1-5 lakh & 57 & 68.33 & 9.11 & & \\
\hline & & 5-10 lakh & 37 & 68.08 & 13.96 & & \\
\hline & & Above 10 lakh & 2 & 70.00 & 15.56 & & \\
\hline & \multirow{4}{*}{$\begin{array}{l}\text { Central } \\
\text { Kerala }\end{array}$} & Below 1 lakh & 66 & 66.74 & 10.60 & 0.334 & $0.801 * *$ \\
\hline & & 1-5 lakh & 56 & 65.84 & 14.06 & & \\
\hline & & 5-10 lakh & 25 & 68.80 & 16.73 & & \\
\hline & & Above 10 lakh & 3 & 69.33 & 4.62 & & \\
\hline & North Kerala & Below 1 lakh & 67 & 65.96 & 12.85 & 0.616 & $0.606^{* *}$ \\
\hline & & 1-5 lakh & 56 & 66.84 & 9.79 & & \\
\hline & & 5-10 lakh & 26 & 68.85 & 9.59 & & \\
\hline & & Above 10 lakh & 1 & 58.00 & & & \\
\hline Length of & South Kerala & Less than 1 year & 23 & 65.17 & 8.52 & 0.676 & $0.510 * *$ \\
\hline association & & 1 to 5 years & 59 & 67.10 & 11.47 & & \\
\hline $\begin{array}{l}\text { with the } \\
\text { bank }\end{array}$ & & $\begin{array}{l}\text { More than } 5 \\
\text { years }\end{array}$ & 68 & 68.28 & 11.84 & & \\
\hline & Central & Less than 1 year & 45 & 63.67 & 14.29 & 4.280 & $0.016^{*}$ \\
\hline & Kerala & 1 to 5 years & 56 & 65.64 & 13.56 & & \\
\hline & & More than 5 years & 49 & 71.00 & 9.81 & & \\
\hline
\end{tabular}


70 | MUDRA: Journal of Finance and Accounting, Volume 4, Issue 2, Jul-Dec 2017

\begin{tabular}{l|l|l|c|c|c|c|c|}
\hline & North Kerala & Less than 1 year & 26 & 66.73 & 10.05 & 2.369 & $0.097 * *$ \\
\cline { 3 - 6 } & 1 to 5 years & 71 & 64.86 & 12.60 & & \\
\cline { 3 - 6 } & $\begin{array}{l}\text { More than 5 } \\
\text { years }\end{array}$ & 53 & 69.25 & 9.28 & & \\
\hline
\end{tabular}
Note: ** Not significant, *Significant
Source: Primary data.

\subsection{Conclusion}

The study found a significant relationship between CRM best practices and customer loyalty to personal profile of the customers, viz. age in south Kerala, occupation in central Kerala, qualification in south Kerala and length of association with bank in central Kerala. But no relationship is found between CRM best practices and customer loyalty to personal profile of the customers, viz. bank, gender, marital status and annual income. It also finds a good association between CRM best practices and customer loyalty in commercial banks in Kerala. It can also be inferred that CRM practices help strengthen customer relationship and contribute to customer loyalty in the long run. Though huge investment is required for a dynamic CRM, timely adoption and effective implementation of the practices splendidly increase the length of customer life cycle. The length of association of customers with the bank also shows that once the customers are satisfied with the services of the bank, they will stick on to that bank for a long period. If their experiences are so patronized they will not think of another bank ever for their transactions. Cross selling, referral marketing, bundling products and services can be used by banks for this purpose. Attractive and comfortable layout for the office and consistency of sales, service and operational processes can create customer satisfaction and strengthen customer life cycle. Reducing paper works, special branch for high-end customers, increased security measures in net banking, systematic database management system, etc. can also offer a 'convenience banking' experience for customers. The study also shows that service quality creates customer loyalty. This highlights the need for enhancement of service quality. Mystery shopping to check employee performance and performance awards to motivate employees are suggested here for the implementation of best practices. As too many customers are a major hindrance to providing quality services, it is ideal to open new branches in areas where there is overcrowding of customers. To conclude, CRM practices help both the public and private sector banks in Kerala in augmenting customer relationship in a greater way and hence it is suggested to adopt advanced CRM practices to strengthen customer loyalty through extension of customer life cycle. 


\section{References}

Bhasker, P.V. (2004). Customer service in banks. IBA Bulletin, XXVI(8), 9-13.

Cronin, M. J. (1998). Defining net impact: The realignment of banking and finance on the web. In Cronin, M. J. (Ed.) Banking and Finance on the Internet. New York: John Wiley \& Sons, pp. 1-18.

Ennew, C. T \& Binks, M. R. (1996). The impact of service quality and service characteristics on customer retention: Small business and their banks in the UK. British Journal of Management, 7(3), 219-230.

Gronroos, C. (1994). from marketing mix to relationship marketing: Towards a paradigm shift in marketing. Management Decision, 32(2), 4-20.

Healy, T. J. (1999). Why you should retain your customers. America's Community Banker, 8(9), 22-26.

Jacoby, J. \& Knyer, D.B. (1973). Brand loyalty versus repeat purchasing behavior. Journal of Marketing Research, 10(1), 1-9.

Das, K., Parmar, J. \& Sadanand, V. K. (2009). CRM best practices and customer loyalty: A study of Indian retail banking sector. European Journal of Social Sciences, 11(1), 6383.

Lassar, W.M., Manolis, C. \& Lassar, S.S. (2005). The relationship between consumer innovativeness, personal characteristics, and online banking adoption. International Journal of Bank Marketing, 23(2), 176-199.

Reichheld, F. F. \& Kenny, D. (1990). The hidden advantages of customer retention. Journal of Retail Banking, 7(4), 19-23.

Wilson, D.T. (1995). An integrated model of buyer-seller relationships. Journal of the Academy of Marketing Science, 23(4), 335-45. 